Article

\title{
The Legal Cause of "Holding Value" and Its Impact on Islamic Provisions Regarding Virtual Currencies
}

\author{
Man Baker ${ }^{1, *(D)}$ and Muhammed Semai ${ }^{2}$ \\ 1 Department of Islamic World Studies, College of Humanities and Social Sciences, Zayed University, \\ Abu-Dhabi 144534, UAE \\ 2 Department of Jurisprudence and its Foundations, College of Sharia and Islamic Studies, \\ University of Sharjah, Sharjah 27272,UAE; msemai@sharjah.ac.ae \\ * Correspondence: man.baker@zu.ac.ae
}

Received: 11 June 2020; Accepted: 7 July 2020; Published: 8 July 2020

\begin{abstract}
This article discusses the Islamic juristic position of virtual currencies. In the classical period, jurists differed on the reason behind Islam's prohibition of usury when dealing with precious metals and their derivatives, with the majority arguing that this is because they are considered to hold value (thamaniyya). The cause ( illa) of "holding value" can therefore be applied through analogy ( $q i y \bar{a} s$ ) to all things understood by the laity to hold value in any era. In the contemporary period, this cause can also be applied to virtual currencies such as Bitcoin if they fulfill the following ethical conditions: customary acceptance, legal validity, and value stability.
\end{abstract}

Keywords: Bitcoin; Islamic Law; virtual currencies

\section{Introduction}

The proliferation of virtual currencies is an important contemporary problem for jurists who strive to determine their ruling according to the Sharī'a. In the past, works in all schools of law (madhāhib) provided guides to their later counterparts for constructing new rulings, based on the belief that "No man can be a jurist of the present if he is not a scholar of the past." ${ }^{1}$

This article is an attempt to analyze the juristic approach to virtual currencies, based upon the works of previous scholars and their framework of "holding value" (thamaniyya), used primarily to establish rulings regarding usury when dealing with gold, silver, and their derivatives. "Holding value," although cited by many as a limited justification, is found regularly in works of jurisprudence. Why, therefore, did jurists seek to limit this justification? Is it possible to expand this view, and state that any item which holds value to the community ('urf) be therefore a legitimate form of currency according to the Sharī a? In other words, this Study examines the ruling on trade of virtual currencies from an Islamic jurisprudence perspective, by building on the reasoning of price established by jurists with regards to gold and silver, and thus introduces a new dimension to the literature of Islamic jurisprudence by adding the legal ruling on this issue. This research contributes to filling this important juristic aspect.

There is no doubt that deciding on the rule of virtual currencies will entail other provisions. If the ruling prohibits trading virtual currencies, it will entail restrictions and its criminalization. However, if the ruling legalizes it, it will entail the emergence of new provisions in terms of determining the legal nature of virtual currencies, determining their value, the rights resulting from trading them, etc.

1 (Ibn 'Abd al-Barr 1994, vol. II, p. 817). 
In this article I will rely upon a deep reading of the works of classical and post-classical jurists, paying attention to their methods of analysis to derive a framework that is closest to the intent of the Lawgiver, accepting the value of non-traditional and virtual currencies. The article covers four sections. The first provides a summary of the relevant terminology used in works of jurisprudence and how those terms link to contemporary understandings. The second section then turns to the value of virtual currencies. The third summarizes the opinions of contemporary jurists regarding this issue, and the fourth section discusses the ethical conditions required by the Sharī'a to establish the value of virtual currencies.

\section{A Summary of Juristic Terms}

As a start, it is important to define three terms which will be used repeatedly as we move on, which are: (al-ta 'līl), Holding Value (al-thamaniyya), and Virtual Currencies (al- 'umla al-iftirādiyya). The first term (al-ta 'lil) means "to drink for a second time." To perform ta lill is "to repeat something." It can also refer to sickness, or that which causes sickness. In general, ta 'ill is "to impact something," or "to move it from one state to another." ${ }^{2}$ Jurists used this term to refer to legal causes in the Shari 'a and explained how to extract them. ${ }^{3}$ According to Abū Bakr al-Jașșāṣ (d. 370/942), "If a text establishes a legal cause [for an issue], we take it to apply to similar circumstances and to establish a ruling for it, as long as it is not blocked by a subsequent prohibition (māni ' )." ${ }^{4}$ For the purposes of this study, the concept ta 'ill refers to the legal cause, particularly as it relates to the Shari' a prohibition of usury on currencies made from gold and silver.

Secondly, Holding Value (al-thamaniyya) is derived from "value (thaman)," and referring to all items through which contracts of sale are conducted, whether in kind or for another product. ${ }^{5}$ Everything that is considered a replacement for the value of something else, therefore, is its "value." In the context of this study, "value" refers to "currency," or that which is popularly accepted by the community as a medium of exchange, regardless of its makeup or condition ${ }^{6}$.

Lastly, Virtual Currencies (al- umla al-iftirādiyya) is composed of two parts: ('umla) and (iftirādiyya). The first one is provided as payment to a worker for services rendered, whether in a form of currency (naqd) or otherwise. Popularly, the term is applied to currencies, as currencies are commonly used by individuals in their everyday transactions. Additionally, in the contemporary period the term 'umla has become a term to refer to anything that holds value (thaman) used to measure the worth of items for sale or exchange, whether a currency or otherwise. ${ }^{7}$ The second part (iftirādiyya) is a derivation of the word fard meaning "supposition, estimation, or approximation." ${ }^{8}$ Combined, these terms refer to a type of non-centralized digital currency, typically issued and controlled by its developers, accepted and used by members of a digital community. Virtual currencies, therefore, may be used in transactions and speculation as any form of non-digital currency, despite possessing none of the characteristics of the latter: it cannot be used in all environments, and it is not subject to control by financial institutions or governments. This is the definition chosen by the Algerian government in its Financial Law of 2018 which states: "Virtual currencies are those utilized by internet users, distinguished by their lack of physical presence such as coins or paper. [It may also include] payments made by financial instruments or bank cards ${ }^{\prime \prime}$.

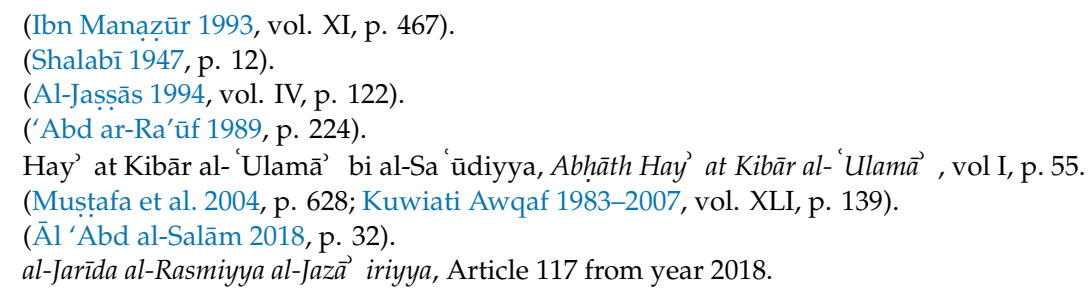


Today, many virtual currencies exist, with each used in a unique and distinct manner, however most of these to date have a limited market value. The most prominent of these currencies are Bitcoin, Bitcoin Cash, Ethereum, Litecoin, Ripple, and Dash.

\section{Juristic Approaches to the Legal Cause of "Holding Value" (al-ta 'līl bi'l-thamaniyya)}

The Sunni schools of law (madhāhib) developed multiple approaches to this issue. Some ruled that a currency should be that which "holds value generally (al-thamaniyya al-ghāliba)," restricting the validity of currencies to those made of or derived directly from gold and silver, while others chose an unrestricted approach to accept anything which holds value (mutlaq al-thamaniyya), and this could include all things that "are popularly accepted as a medium for the exchange of goods, regardless of the material from which it is derived." 10 The source of that validity is customary acceptance ( urf), according to Ibn Taymiyya (d. 728/1328) who stated, "There is no physical or legal definition of dirhams and dinars, rather they are [defined by] custom, because [currency] is not connected to [the material] which it is derived from. Rather, [a currency's] purpose is to act as a standard by those who use it. Dirhams and dinars are not a purpose in themselves, but instruments that are dealt with [in contracts.] Currencies, [as a result of being considered instruments,] gain value. An instrument that does not contain that purpose in its material or shape gains that purpose [through customary acceptance.]"11

After hundreds of years, the same opinion was echoed by the Egyptian reformist Rashid Rida ${ }^{12}$ who stated-When discussing the opinions of pre-modern jurists regarding the legal reasoning behind the prohibition of usury when dealing with the six materials mentioned in a famous Hadith regarding usury, ${ }^{13}$ " The middle opinion is that the six materials mentioned in the Hadith were and still are considered standards of value and staples for the diets of most of humanity. Accordingly, If this legal cause [viz. being a standard of value] is found in any currency other than gold and silver, or in a staple other than wheat, barley, dates, or salt, it is correct to apply that cause through analogy [to the new currency or staple,] as they are interchangeable [legally], and the same legal ruling should apply."14.

This approach -the general and unrestricted definition supported by Ibn Taymiyya and Rashid Rida-, is consistent with the purposes of the Lawgiver (maqāsid) and follows their foundations, as dirhams and dinars- both derived from valuable metals (silver and gold respectively)- are not considered as having value simply by virtue of the material that they are created from. Rather, they are instruments with which commercial exchange takes place. Therefore, -according to them-currencies may be in the form of gold and silver, coins and paper, or whatever is found to fulfill that purpose in every time and place. ${ }^{15}$

The gold and silver are materials that hold inherent value regardless of their form and application. Gold bars, for example, may be used in commercial exchange and hold value even before they are minted, an attribute absent in other metals or paper which must first be minted or printed into a currency. Ibn Taymiyya stated that "During the time of the Prophet Muhammad, people used gold and silver sometimes in the form of currency, and at other times simply by measuring the weight [of the non-minted metal]."16

Therefore, the use of paper currency, or whatever else might have existed or will exist in the future, as a medium of exchange, does not alter the legal cause of "holding value." The legal cause is also not changed by the existence of money, bars, dust, or jewelry made from gold and silver, because the

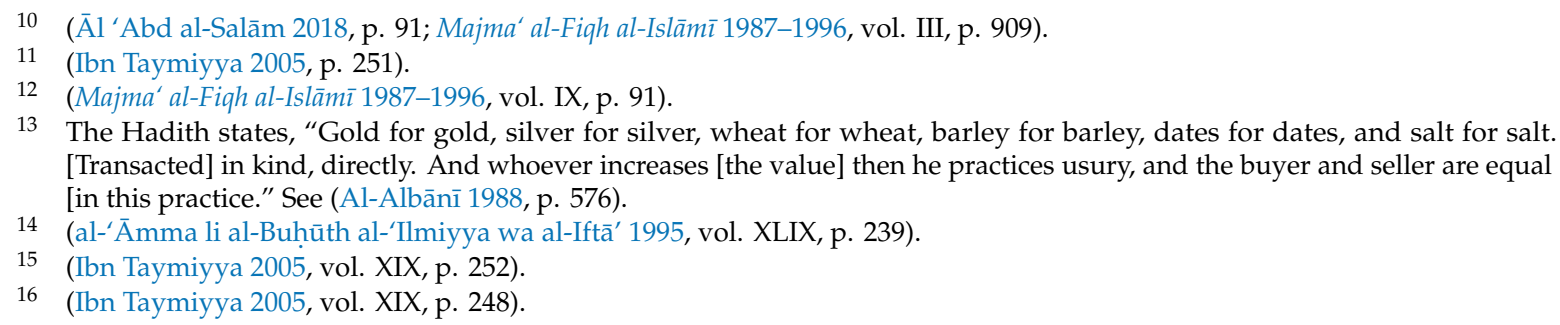


practice of the Prophet made it a requirement that gold and silver be traded equally and physically at the point of exchange, as they are the foundation of monetary value, and all other materials are analogous to them.

\section{The Value of Virtual Currencies}

The study of virtual currencies means approaching a recent development that Muslim scholars have yet to develop a clear understanding of, and a significant amount of effort remains with regards to the position of virtual currencies within the Sharīa. Perhaps the best way to approach this issue is through the classical method of analogy (qiyās), developed by scholars to apply a clear legal cause ( iilla) established for certain items onto new situations. The juristic approach to coins and paper currency, and whether they carry the same ruling as currency made from precious metals such as gold and silver, is the most appropriate area of substantive law that this study will use to reach the correct ruling in the matter of virtual currencies, i.e., that closest to the will of the Lawgiver. Therefore, studying classical opinions regarding the value of (fulūs)will help us reach a balanced ruling.

Apparently, pre-modern Jurists differed regarding the ruling of money (fulūs), or material that is minted and used as currency, accepted by the people as valid for use in their daily interactions, and not made of gold or silver. ${ }^{17}$ Some looked to money's use, considering it as merely another type of item used in bartering that required no new ruling. Others focused on the importance it was given by people in their commercial interactions, assigning it the same ruling as that of gold and silver due to money "holding value (thamaniyya)." Ibn Taymiyya summarized these opinions, stating, "There is an infamous disagreement amongst scholars in this issue, meaning the exchange of money for [silver] dirhams. Does it require the passage of a year [in order for zakat to become obligatory]? Can [money] be used in delayed purchases? There are two famous opinions here: one from the school of Abu Haniffa and one [from the school of] Ahmad b. Hanbal. The first, and that is what is written regarding [the opinion] of Ahmad [b. Hanbal], the statement of Mālik [b. Anas] and one of two narrations from Abu Hanīfa, is that it [viz. money] is not permitted. The second, and that is the statement of al-Shāfi ' 1 and the second narration of Abū Hanīfa and Ibn 'Aqīl, the student of Ahmad, that it [viz. money] is permissible. The evident [ruling], therefore, is that it is prohibited. ${ }^{18}$

The approach of the majority of Hanafī, Mālikī, and Hanbalī jurists is that popularly used money is given the property of "holding value," and that it carries the rulings of currency like gold and silver. Subsequent rulings of zakat and usury also apply in the same way, and that it may not be exchanged with itself unless it follows the requirements of the Hadith, or that it is of the same kind, condition, and done immediately.

In the Maliki treatise al-Mudawwana the transmitter of the treatise, 'Abd al-Rahmān b. al-Qāsim (d. 191/806), was asked about the delayed exchange of money for silver dirhams. "Do you not see that if you purchased money with silver dirhams, that we have parted before completing the exchange?" Ibn al-Qāsim responded, "This [exchange] is not permitted in the opinion of Mālik, and this is a corrupt [practice]. Mālik once said that 'there is no good in money, whether in [the form of] gold or paper. Even if people began exchanging animal skins between themselves as a form of currency, I would render it unacceptable that it be purchased for with gold, or similarly paper." ${ }^{\prime 19}$ In the same context, we can read in the Hanafi work Badā' i' al-Sanā' i', the author 'Alā' al-Dīn al-Kāsānī (d. 587/1191) cites the statement of Muhammad b. al-Hassan (d. 198/805), the student of Abū Hanīfa (d. 150/767), who prohibited the mutual exchange of money with a difference in value. "His reasoning," stated al-Kāsānī,"Is that money is 'valuable.' It is [therefore] not permissible to exchange it for itself with a difference in value just like [gold] dinars and [silver] dirhams. The point of argument is how the

\footnotetext{
See (Al-Fayūmī 1977, vol. II, p. 481).

(Ibn Taymiyya 2005, vol. XXIX, p. 468).

9 (Al-Madanī 1994, vol. III, p. 5).
} 
financial value of things is calculated, and things whose value can be calculated with dirhams and dinars can be done so with money, meaning that money is 'valuable.' Money is considered 'valuable' when transacted with other things, or when transacted with other forms of itself if it is done equally. As money 'holds value' it does not constitute a 'good.' Selling one unit of money for two units of money without an [additional] exchange of goods is not permissible. This is because exchanging one unit would be equal to the other, and that the additional unit would be excess not traded for anything. This is the very definition of usury (ribā). ${ }^{20}$

Finally, the Hanbali jurist 'Alā' al-Dīn al-Mardāwī (d. 885/1480) stated, "Money that is spent [on goods] is 'valuable.' This is a common statement of our school. Ibn Rajab said this, and al-Shīrāzī in al-Mubahhaj chose the opinion that money is 'valuable' in every state, and it carries the rulings of all things that 'hold value,' in that it is permissible to conduct delayed exchanges with them." 21

Therefore, most jurists agreed that money is a form of "holding value," evidenced by:

1. Analogy (qiyās) with money derived from gold and silver, due to the shared legal cause of "holding value" between each of them. The legal cause of "holding value" is therefore more preferable towards the goal of prohibiting usury than an alternative legal cause established through other characteristics such as "weight." In support of this point, the Hanbali jurist Ibn Qayyim (d. 751/1350) stated,"This is the correct [approach]. There is consensus on the point that the legal cause of 'weight' is effective in metals commonly judged by their weight like copper and iron. If usury is possible in the exchange of copper and iron, it would not be permissible for them to be sold or bought in a delayed purchase in exchange for silver dirhams, as it is permissible to exchange items in which usury is possible with an inflation in price, but not with delayed delivery. When a legal cause occurs without causing a significant difference, that is evidence that it is invalid. Therefore, the legal cause of 'weight' is not appropriate as it merely a characteristic, as opposed to the legal cause of 'holding value.'22

2. The ruling of Ibn Taymiyya, which states, "That the purpose of valuable items is that they act as a standard for wealth, or that they are used to measure wealth. There is no intent to take advantage of them in themselves. When some [valuable items] are sold in a delayed exchange for other [valuable items], they are intended to be used in commerce that contradicts the purpose of 'holding value.' If money is 'holding value' then the meaning holds: that an item that holds value cannot be exchanged for the same in a delayed purchase. ${ }^{\prime 23}$

That all items considered to be a measurement to know the value of what they own and relied upon by people to set the prices of goods are to be legally considered as items which "hold value." The rulings of this general category then apply: they cannot be exchanged for themselves with a difference in value, or exchanged with other items at a later time, preventing people from falling into corrupt practices like speculation. Ibn Qayyim, speaking to the harm caused by people taking money as a good that is bought and sold like others, stated, "When money was taken as a good from which one can profit from harm occurred and injustice prevailed. If money was treated with a set value that did neither increased nor decreased, rather other items were judged by it, then the matters of people would be repaired." 24

\section{Statements of Jurists in the Value of Paper Money}

Paper money is a recent innovation, one that jurists have struggled to determine a ruling for. Some considered it as a debt certificate, while others have considered it as a stand-in for gold and

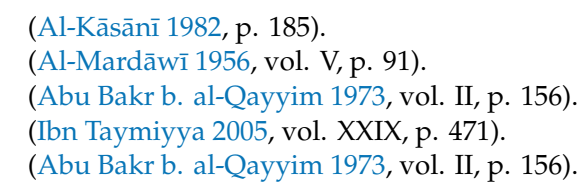


silver. Still others considered it as a new form of independent currency. Types of paper money are as diverse as the nations that produce them and, as a result, it is the third opinion that most contemporary scholars have settled upon and has been accepted by Arab and Islamic governments ${ }^{25}$ for several reasons, namely:

1. The similarities in "holding value" that exist between paper money and gold and silver, and the commercial instability and injustices that would take place if these monies were treated as goods to be bought and sold. Therefore, paper money was independently given the rulings of gold and silver, not because they follow their legal characteristics.

2. The common agreement of individuals in a society to conduct transactions with paper money with an almost absolute trust. They have made money the primary method of storing wealth and imbued it with enough strength to conduct sales, establish legal obligations, and made it a standard to determine the value of their fixed and movable property. This has all taken place against the backdrop of strict legal protections, with governments prosecuting all those who attempt to alter or counterfeit it.

3. That the diverse financial institutions that issue paper money have taken advantage of this trust to take the place of gold and silver and built on the public's acceptance of paper money. Their diversity is both a strength and weakness, in that financial institutions have proven that each form of paper money is a unique type.

This is the position that most Islamic organizations in the Arab and Islamic World have settled upon. This is because all nations of the world have settled upon the use of paper money, that paper money has almost become the sole way through which individuals conduct their business, that the legal cause of 'holding value' has been established for it, and that it has taken the characteristics of currency.

With this in mind, it must therefore be confirmed that "holding value" is the established legal cause when determining the legal validity of forms of money and currency, and that the use of paper money - or any other type for that matter-does not alter the validity of the legal cause. Nor does it impact the ruling of money made from gold and silver, as the Sunna of the Prophet requires that they be bought and sold only in the moment and the same type, prohibiting delayed sales. Gold and silver are the origin, and "holding value" is the intrinsic element through which analogy can be made. The determining factor of "holding value" for any item other than gold and silver, therefore, is customary acceptance.

\section{Contemporary Juristic Opinions on the Value of Virtual Currencies}

After establishing the near-complete juristic agreement regarding the value and validity of paper currencies, the issue is then regarding applying whether the same legal reason can be applied to virtual currencies through analogy (qiyas). The strongest path to establishing that analogy would be to confirm virtual currencies as a new form of money, as the Shar '⿳亠 $r$ ruling is based on the presence or absence of the same legal cause. In the words of Ibn Qayyim," The Sharīa is the ultimate wisdom and cares for the public good. It neither separates things which are similar, nor combines things which are different. The Sharī a does not prohibit a thing to bring corruption or permit something whose corruption is equal to that which is prohibited. The Sharī a also does not permit something to bring a benefit or prohibit something whose benefit is equal to that which is permitted. The Shari a brought by the Prophet contains none of these things". ${ }^{26}$

Contemporary jurists have differed when it comes to virtual currencies, owed to the classical difference of opinion found in establishing the validity of the legal cause of "holding value." The majority

25 (Majma' al-Figh al-Islāmī 1987-1996, vol. IX, p. 91).

26 (Ibn al-Qayyim 1992, vol. I, p. 1072). 
have leaned towards prohibition, worried about the applicability of the legal cause on these contrived financial instruments. As a result of this approach, most of financial organizations in the Arab and Muslim Worlds have prohibited their use, with some considering it a crime to trade in virtual currencies, considering it a threat to the financial stability and currency of the country. ${ }^{27}$

Jurists who differ with this approach have not gone so far as to permit the use of virtual currencies outright and stopped short of issuing a final ruling, suggesting that further research is needed before virtual currencies are accepted as a legal alternative to paper money. ${ }^{28}$ They have also added the condition that if virtual currencies are to be accepted, they must be regulated, and that the owners of blockchains be granted rights and responsibilities in the real world. Looking at their opinions, we can see their reasoning is focused on Subjective and external reasons.

Subjective reasons mean-according to them- the nature of virtual currencies without a consideration of their impact or legal consequences, as they are entirely electronic and exchanged only through the internet. It is therefore impossible to understand them as holding or assessing value, as "they are a decentralized digital currency that has no legal presence and cannot be exchanged in any physical manner." ${ }^{29}$ Moreover, virtual currencies are shrouded in secrecy and little is known about them, meaning that any criminal could take advantage of them and defraud others. It is established in Islamic Law that fraud and uncertainty are the main reasons for prohibiting commercial acts. In a sound hadith on the authority of Abū Hurayra, "the Prophet prohibited uncertainty in sales." ${ }^{30}$ Consensus also exists in the prohibition of uncertainty and fraud, and the Hanbali jurist Ibn Qudāma (d. 620/1223) stated, "We know of no difference [of opinion] in this matter." 31

External reasons focus on the impact virtual currencies might have on central banks and national financial institutions, and that international smugglers and criminal organizations might use virtual currencies to commit their crimes and launder money, escaping justice through the anonymity of the virtual world. This is quite possible, and the Religious Affairs Ministry of the UAE has stated that, "Using virtual currencies in their current state lead to dangerous consequences, whether for users, financial markets, or all of society. Whether they are legally considered as money or goods, the resulting ruling is the same." ${ }^{\prime 32}$

Beyond these reasons, there is another juristic opinion that views blockchain technology as a reality, and that virtual currencies have become inevitable as they continue to gain popular trust and acceptance. According to a recent study, "It is not inconceivable that initial opinions will seek to prohibit virtual currencies as the risks are high and they are unknown in most nations, making dealing in virtual currencies seem like a risky gamble. As virtual currencies become a foregone conclusion around the world that opinion will change."33

Echoing this opinion, the economic consultant of the Russian Fatwa Council stated, "The Islamic community in Russia, particularly that in the Caucasus, actively discuss the issue of virtual currencies." She believes that the characteristics of these currencies might render them "permissible (halāl)," except that multiple jurists have not begun to entertain this approach. The main issue worries Muslim authorities is that there exists no unified organization that issues or regulates virtual currencies. ${ }^{34}$

27 Such is the case in Algeria, where a 2018 law banned transactions in Bitcoin, warning users of the currency that they would be liable to criminal punishments.

28 Some nations, such as Japan, are currently studying the possibility of replacing their paper currency with a virtual currency to reduce the burden managing paper currency has on their national economy. Counterfeiting of virtual currencies, if properly controlled and legalized, is much more difficult than paper currency. The Russian Central Bank has also recently announced that it would begin issuing a national electronic currency, and the Russian government is currently working on the laws and regulations that would allow for the legal use of their new virtual currency.

29 (Rif'at 2017).

30 (Muslim 2004, vol. III, p. 1153).

31 (Ibn Qudāma 1984, vol. IV, p. 294).

32 (al-Hay' a al- 'Āmma li al-Shu' ūn al-Islāmiyya wa al-Awqāf, UAE. Fatwa Number 89043, 30 January 2018, Ḥukm at-Ta 'āmul bi al-Bitcoin).

33 (Āl'Abd al-Salām 2018, p. 81).

34 (Ghāyirlī 2017). 


\section{Shar ì Conditions That Establish the Legal Cause of "Holding Value" for Virtual Currencies}

This study now turns to the possibility of establishing the legal cause of "holding value" for virtual currencies in their various forms. Using opinions established in the classical schools of Islamic Law (madhāhib), it can be proven that the characteristic of "holding value" of any item not made from gold and silver can be applied if that thing meets the following conditions:

First: That there is a customary acceptance of that characteristic and that all or most people accept that this item is suitable for establishing the value of things. Customary acceptance requires "that people of sound mind accept and are comfortable with a thing," and a currency may not be considered as "holding value" by people unless they trust it completely as a vessel for holding their wealth, a medium of exchange in all of their transactions, and a stable measurement used to obtain their rights.

The most important condition of the Sharī' a for establishing an item as "holding value" is that it is: "Accepted as a medium for purchases and financial transactions. This means that it is possible to be used widely to buy and sell things, not only limited exchange based on mutual consent between a limited number of parties. If two individuals conduct a sale and one person offers clothes in exchange for food, neither the food nor the clothes will be considered as money. However, if we assumed that these particular clothes are widely-accepted as interchangeable for any other good, and people begin saving clothes to exchange in times of need not simply because they are clothes but because they store value, they would then take the legal ruling of money". ${ }^{35}$

Second: That the virtual currency is largely stable. This is because items that "hold value" must be, according to Ibn Qayyim," A standard known for establishing the value of wealth. The currency must be limited and stable, not increasing or decreasing [in value]. If the value increase and decreases like with other goods, it cannot be understood as 'holding value' and used to determine the worth of other goods. Rather, it is a good just like everything else. People have an inherent general need for a currency that they can use to value purchases, and that can only be achieved through an item that establishes the value of other things and continues in a unified state. Its value cannot be determined inversely, as the value of other goods rises and falls. [If so], the transactions of people will be corrupted, differences and harm will arise, as has been seen in the resultant harm when people treat money as a product they can profit from. Harm spread and injustice occurred. If there was only one form of currency whose value neither increased nor decreased, was used to value things, and could not be valued by other things, then the matters of the people would be resolved. ${ }^{36}$

Third: That the virtual currency is recognized by the state. This is because the establishment of currencies is the sole responsibility of the state and the state alone may issue currency, according to the rules and regulations it sets. There is no difference here between currencies from gold and silver or other items, as classical jurists are clear that the issuance and minting of currency is among the responsibilities of the political leader (Imām) and his representatives, in order to prevent instability, chaos, fraud, and counterfeiting. One of the greatest roles and purposes of the Sharī' a is to protect people's wealth. As a result, most jurists have created this condition.

For example, the Hanbali jurist Manșūr b. Yūnus al-Bahūtī (d. 1051/1641) stated,"Imam Ahmad used to say that it is not possible for any institution other than the official mint with the permission of the Sultan to produce currency, because if people could produce their own currencies great calamities would ensue. The Judge [al-Māwardī] stated in the al-Ahkām al-Sultāniyya stated, 'The minting of currency can only occur with the permission of the Sultan, due to the risk in this matter. ${ }^{\prime 37}$ Likewise, the Shāfi î jurist al-Nawawī (d. 676/1277) stated, "It is disliked (yukrah) for subjects to mint currency even if it is pure, because the issuance of currency is the purview of the Imam." ${ }^{\prime 38}$

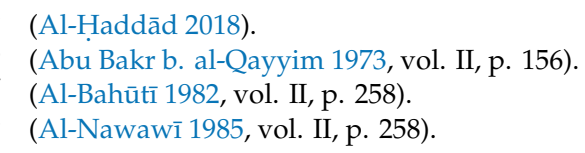


Therefore, the issuance of currency, whether real or virtual, is the right of the Imam alone. The Kuwaiti Encyclopedia of Islamic Law states, "There must be a delegation of power to mint currency to distinguish the pure from the counterfeit. Fraud and counterfeiting are prevented with the recognizable stamp of the political authority, and it is not permissible for anyone other than the Imam to issue currency, as by doing so is an assumption of his authority. It is permissible for the Imam to punish at his discretion whomsoever assumes his authority, whether the [currency he has] minted is like that of the political authority or not.".39

Based on the current legal discussion around virtual currencies, this study notices that virtual currencies are unable to fulfill any of the three conditions discussed above:

- Regarding the first condition, Bitcoin and other virtual currencies like it are still only used in limited circles, and it is impossible to say that a society acknowledges virtual currencies, much less considers them to be an accepted medium of exchange. The reason for this is clear: that people are accustomed to only working with currencies issued by the state, "as the state preserves value, providing the currency it issues with the legal protection that allows it to perform its most basic task: to act as a measurement of the value of goods and a mechanism to resolve debts." 40

- Regarding the second condition, virtual currencies are fleeting and unfixed, far from the widespread use required to ensure the characteristic of "holding value." This is because it has no real value either intrinsically or externally. Virtual currencies are based on nothing and could collapse or disappear at any moment as a result of any condition. Clearly, these are not stable currencies that can be relied upon as measurements of the value of goods nor a mechanism to store wealth. Experts have also pointed out that "The value of virtual currencies fluctuate greatly over a short period of time. They change according to circumstances in the market, while paper currencies are mostly determined by the strength or weakness of their corresponding national economy. The stability of paper currency cannot compare to that of virtual currencies." ${ }^{11}$

- Regarding the third condition, virtual currencies remain contrived and that they have no physical existence, nor are they connected to any official national or international financial institution. This means that they have no foundations or holdings and are not protected by rules or regulations. They are not subject to any form of institutional oversight, making virtual currencies difficult to follow much less guarantee. The UAE Ministry of Islamic Affairs stated, "A currency in the modern understanding takes the Shar $\overline{1}$ and secular legal ruling if it meets the following standard: that is issued by the state and protected by its laws. This is to assure people when they deal with it that their rights are preserved and their obligations fulfilled." 42

The above shortcomings have only one meaning: that the Shar ' 1 legitimacy of these currencies has not yet been proven. In the words of the report from the UAE Ministry of Islamic Affairs, The ruling of virtual currencies, which has become a major point of public discussion and are still outside the oversight provided by responsible government agencies, could differ if rules and regulations were issued that made virtual currencies subject to oversight. That way, virtual currencies would gain the advantage of legality in their use between both individuals and nations".

\section{Conclusions and Results}

Unrestricted legal cause of "holding value" to prohibit usury in gold and silver is the closest and most authentic legal cause available to reach the intent of the Lawgiver, with regards to the permissible

39 (Kuwiati Awqaf 1983-2007, vol. XLI, p. 178).

40 “. al-Hay' a al- 'Āmma li al-Shu’ ūn al-Islāmiyya wa al-Awqāf, UAE. Fatwa Number 89043, 30 January 2018, “Hukm at-Ta āmul bi al-Bitcoin,".

41 (Ảl-Haddād 2018).

42 al-Hay' a al- 'Āmma li al-Shu’ ūn al-Islāmiyya wa al-Awqāf, UAE. Fatwa Number 89043, 30 January 2018, “Hukm at-Ta 'āmul bi al-Bitcoin,". 
transactions that fulfill the common needs of the Believers. That "holding value" is not a limited cause ( 'illa qāșira). Rather, it is overarching, and people of any time period may use the concept to assign value to what they consider as an appropriate standard to establish the value of goods and services. Also, That the "value held" by gold and silver is inherent in these metals and does not change according to their condition. The "value held" by other physical and virtual materials is determined by custom, capable of changing according to the juristic principle: "It is not to be denied that rulings change with the passage of time."

All the studies that have been completed on the validity of virtual currencies are personal interpretations that only reflect the opinion of their authors. Both forms of currencies possess no inherent value but are dependent upon external factors: that they are accepted through custom and law as a trusted medium of exchange and are a widespread and managed standard of exchanging and storing wealth.

It is not possible to establish a definitive Sharīa position on the matter. However, it can be stated that blockchain technology and virtual currencies are a reality on the ground that have received a large amount of backing and trust, and that there is no Shar '⿳亠丷⿵冂⿱十口 prohibition preventing their acceptance.

Finally, it is imperative that legal scholars and experts not rush to issue rulings and fatwas regarding this or other contemporary matters. The question of virtual currencies requires group rulings from official fatwa houses, committees, research institutes, and religious and economic university departments alike.

Author Contributions: Conceptualization, M.B. and M.S.; methodology, M.B. and M.S.; formal analysis M.B. and M.S.; resources, M.B. and M.S.; writing—original draft preparation, M.B. and M.S.; writing—review and editing, M.B. and M.S.; funding acquisition, M.B. All authors have read and agreed to the published version of the manuscript.

Funding: This research received no external funding.

Conflicts of Interest: The authors declare no conflict of interest.

\section{References}

'Abd ar-Ra'ūf, Muhammad. 1989. at-Ta 'ārīf, 1st ed. Beirut: Dār al-Fikr.

Abu Bakr b. al-Qayyim, Muhammad b. 1973. I'lām al-Mawqa' ìn 'an Rabb al- 'Ālamīn. Beirut: Dār al-Jīl.

Āl 'Abd al-Salām, Yāsir 'Abd al-Raḥmān. 2018. al- 'Umlāt al-Iftirāạiyya, 1st ed. Riyadh: Dār al-Mayman.

Al-Albānī, Muḥammad Nāsir al-Dīn. 1988. Saḥ̄ḥ wa Da ì̃ al-Jāmi al-Saghīr wa Ziyādatuhu. Beirut: Al-Maktab al-Islāmī.

Al-Bahūtī, Manșūr b. Yūnus. 1982. Kashshāfal-Qanā'. Beirut: Dār al-Fikr.

Al-Fayūmī, Aḥmad b. Muhammad. 1977. al-Miṣbāh al-Munīr fì Gharīb ash-Sharh al-Kabīr, 2nd ed. Cairo: Dār al-Ma ārif.

Al-Haddād, Haytham b. Jawād. 2018. Available online: https://dorar.net/article/ (accessed on 24 January 2020).

Al-Jaṣsās, Aḥmad b. 'Ali. 1994. al-Fuṣūl fi al-Uṣūl, 2nd ed. Kuwait: Wizārat al-Awqāf al-Kuwaitiyya.

Al-Kāsānī, 'Alā' al-Dīn. 1982. Badà i' al-Sanàa i' fì Tartīb al-Sharā̉ i'. Beirut: Dār al-Kitāb al- 'Arabī.

Al-Madan̄̄, Mālik b. Anas. 1994. al-Mudawwwana al-Kubrā. Beirut: Dār al-Kutub al- 'Ilmiyya.

Al-Mardāwī, 'Alī b. Sulaymān. 1956. al-Inṣāffì Ma rifat al-Rājiḥ min al-Khilāf, 1st ed. Beirut: Dār Ihyā̄' al-Turāth al- 'Arabī.

Al-Nawawī, Yahya b. Sharaf. 1985. Rawdat al-Tālibìn wa 'Umdat al-Muftīn. Beirut: al-Maktab al-Islāmī.

Ghāyirlī, Farīd. 2017. 'Umla Raqmiyya 'Halāl' fī Rūsīā. Russia Today. November 1. Available online: https://arabic. rt.com/business/907732-/\%3C\%D8\%B9\%D9\%85\%D9\%84\%D8\%A9-\%D8\%B1\%D9\%82\%D9\%85\%D9\% 8A\%D8\%A9-\%D8\%AD\%D9\%84\%D8\%A7\%D9\%84-\%D8\%B1\%D9\%88\%D8\%B3\%D9\%8A\%D8\%A7\%3E/ (accessed on 26 May 2020).

Ibn 'Abd al-Barr, Yusūf b. 1994. 'Abd Allāh, Jāmi` Bayān al- 'Ilm wa Faḍlihi, 1st ed. Dammām: Dār Ibn al-Jawzì. Ibn al-Qayyim, Muhammad b. Abī Bakr. 1992. Bada’ i'al-Fawa’ id, 1st ed. Mecca: Maktabat Nazār Muṣtafa al-Bāz. Ibn Manạūūr, Muhammad b. Makram. 1993. Lisān al- 'Arab, 1st ed. Beirut: Dār Sādir.

Muslim, b. al-Hajjāj. 2004. Saḥ̂̄h Muslim. Beirut: Dār Ihyā'’ at-Turāth al- 'Arabī, NA. 
Ibn Qudāma, 'Abd Allāh b. Aḥmad. 1984. al-Mughnī, 1st ed. Beirut: Dār al-Fikr.

Ibn Taymiyya, Aḥmad b. 'Abd al-Halīm. 2005. Majmū' al-Fatāwa, 3rd ed. Alexandria: Dār al-Wafā' .

Muștafa, Ibrāhīm, Ibrahim Anis, Abdel Halim Montaser, Attia Al Sawalhi, and Muhammad Khalaf Allah Ahm. 2004. al-Mu jam al-Wasìt. Cairo: Dār al-Da 'wa.

Al-Mawsū' a al-Fiqhiyya al-Kuwaitiyya, 2nd ed. 1983-2007. Kuwait: Wizārat al-Awqāf.

Majallat Majma al-Fiqh al-Islāmī. 1987-1996. Jeddah: Organization of Islamic Cooperation.

“Hukm at-Ta'āmul bi al-Bitcoin," al-Hay'a al-'Āmma li al-Shu'ūn al-Islāmiyya wa al-Awqāf, UAE. Fatwa Number 89043. 30 January 2018.

Majallat al-Buhūth al-Islāmiyya. 1995. Riyadh: al-Ri' āsa al- 'Āmma li al-Buhūth al- 'Ilmiyya wa al-Iftā' . Available online: https://www.awqaf.gov.ae/ar/Pages/FatwaDetail.aspx?did=89043 (accessed on 15 May 2020).

Rif‘at, Ismā '̄il. 2017. al-Bitcoin Harām Shar 'an bi Amr min Dār al-Iftā’ . al-Youm al-Sābi ', December 31.

Shalabī, Muhammad Muṣtafa. 1947. Ta lìl al-Ahkām, 1st ed. Cairo: al-Azhar Press.

(C) 2020 by the authors. Licensee MDPI, Basel, Switzerland. This article is an open access article distributed under the terms and conditions of the Creative Commons Attribution (CC BY) license (http://creativecommons.org/licenses/by/4.0/). 